\title{
Perancangan Mobile Application untuk Startup montirkeliling.com dengan Metode Design Sprint
}

\author{
Nur Rohman Ashshiddiqy ${ }^{1}$, Ni Luh Putu Ning Septyarini Putri Astawa ${ }^{2}$, Bagus Putu Wahyu Nirmala ${ }^{3}$, A.A Istri Ita \\ Paramitha $^{4}$ \\ Program Studi Sistem Informasi \\ Sekolah Tinggi Manajemne Informatika dan Komputer \\ Denpasar, Bali, Indonesia \\ E-mail : shiddiqculess14@gmail.com, ningseptyarini28@gmail.com, bagus.p.wahyu@gmail.com, ita@primakara.ac.id
}

\begin{abstract}
The development of technology today is very influential in all fields. Including in the business field, information technology is very influential, for example, today many businesses depend on websites orapplications mobile in carrying out their business processes such as promotion and ordering of products or services offered. One example of a business that can use this business method is call vehicle service services. The problem found from initial observations is that online service orders are still very manual, namely still using thefeature chat (WhatsApp), which makes potential customers and mechanics find it difficult to find a mechanic or the location of the customer. Based on these problems, the researchers designed the user interface for the Montirkeliling.com application based on aapplication mobile that can help prospective customers and mechanics. The design method used is themethod sprint design. This method is a design method developed by Google Inc. which aims to solve problems by involving users through making, prototyping, designing and testing ideas quickly for 5 working days consisting of five stages. The result of this research is the design of the Montirkeliling.com User Interface which has been tested on prospective users using the System Usability Scale (SUS). The average SUS score obtained is 83.5, which is included in Grade B.
\end{abstract}

Keywords-Planning, Startup Montirkeliling.com, Metode Design Sprint

\section{PENDAHULUAN}

Berdasarkan data sensus penduduk 2019, jumlah penduduk di Bali tahun 2019 mencapai 4.336,9 ribu jiwa dan dari jumlah penduduk tersebut 450.210 jiwa memiliki mobil penumpang dan 3.738.803 jiwa memiliki sepeda motor[1]. Dapat dilihat dari data tersebut, penduduk di Bali yang memiliki kendaraan terbilang cukup banyak dan masing-masing orang tersebut memiliki rutinitas, kegiatan, dan masalah yang tentunya berbeda-beda pula. Dan dari hasil observasi awal yang dilakukan dengan penyebaran kuesioner terhadap 100 calon pelanggan, 90/100 calon pelanggan mengalami kesulitan terhadap pencarian montir atau tempat servis untuk kendaraan mereka. Hal tersebut disebabkan oleh kesulitan dalam menemukan montir karena di tempat yang baru ataupun dikarenakan memiliki kesibukan yang padat.

Perkembangan teknologi saat ini sangat berpengaruh terhadap segala bidang. Tentu saja dalam bidang bisnis, teknologi informasi sangat berpengaruh contohnya saat ini banyak bisnis yang bergantung pada website dan aplikasi mobile dalam proses menjalankan bisnisnya seperti promosi produk atau pemesanan jasa yang ditawarkan. Salah satu contoh bisnis yang bisa menggunakan cara bisnis tersebut, yaitu jasa servis kendaraan panggilan. Mengingat kondisi saat ini masih dilanda dengan pandemi COVID-19 yang mengharuskan untuk menjaga jarak yang entah sampai kapan pandemi ini berakhir.

Banyaknya kejadian yang tidak dinginkan terjadi saat diperjalanan atau dirumah ketika perlu untuk menggunakan kendaraan seperti kendaraan yang mendadak rusak, ban kempes, butuh derek, macet atau mogok dan kejadian lainnya yang membuat membutuhkan jasa servis untuk memperbaiki kendaraan. Namun, dikarenakan tidak mengetahui dimana tempat yang menyediakan jasa servis dikarenakan dalam perjalanan luar kota yang menyebabkan tidak mengetahui daerah tersebut atau disaat tidak memiliki waktu dikarenakan memiliki kesibukan yang tidak bisa ditinggalkan, membuat calon pelanggan merasa kesulitan untuk memanggil jasa servis yang memiliki kriteria yang dibutuhkan seperti minimnya informasi, harga, dan sulitnya menemukan jasa servis yang melayani jasa panggilan ke tempat. Permasalahan serupa juga ditemukan pada penelitian oleh Ida Ayu Ratih Ardiyanti pada tahun 2019[2] yang membangun mobile apps Griyamua untuk mengatasi masalah tersebut. 
e-ISSN: 2685-7006 | p-ISSN: 2252-9063

Kumpulan Artikel Mahasiswa Pendidikan Teknik Informatika

(KARMAPATI)

Volume 10, Nomor 3, Tahun 2021

KARMAPATI

Montirkeliling.com hadir untuk menjawab segala permasalahan tersebut untuk menyediakan jasa panggilan servis yang memiliki standarisasi sendiri untuk montir dan pelayanannya, namun sistem booking di montir keliling saat ini masih tergolong manual yaitu menggunakan aplikasi chat (Whatsapp) yang di mana tidak menutup kemungkinan terjadi kesalahan baik dalam segi ketidaksesuaian ataupun human error. Serta kesulitan bagi calon pelanggan untuk menghubungi jika tidak memiliki kontaknya dan tidak bisa mengetahui berapa perkiraan bujet yang dikeluarkan untuk jasa servis yang digunakan.

Monitrkeliling.com merupakan sebuah startup yang bergerak dibidang jasa servis panggilan kendaraan yang mempunyai standarisasi tersendiri untuk pelayanan dan montir yang dimiliki.

Permasalahan yang telah dibahas diatas dapat juga ditemukan pada e-marketplace catering oleh Muhammad Andrean dkk, membuat sebuah aplikasi Sistem Informasi eMarketplace Catering berbasis Android yang berfungsi untuk mempermudah user atau pengguna untuk mencari catering dan melakukan pemesanan dan untuk untuk membantu pengelola agar bisa memasarkan produknya secara lebih luas dikarenakan sarana promosi yang dilakukan masih tergolong tradisional yaitu melalui brosur dan mulut ke mulut yang dimana produk yang dipasarkan belum banyak dikenal oleh masyarakat[3].

Dapat ditemukan juga permasalahan tersebut pada pada penelitian Putu Sidarta pada tahun 2018 mengenai emarketplace penyewaan lapangan futsal. Sistem booking penyewaan venue masih sangat tergolong tradisional yang mengharuskan calon pelanggan harus menghubungi langsung pihak penglola lapangan futsal yang dimana hal ini dinilai tidak efisien dalam hal penghematan waktu dalam proses booking. Aplikasi ini berguna untuk memudahkan calon pelanggan mendapatkan informasi secara real-time tanpa harus datang langsung atau menanyaka kepada pihak pengelola lapangan[4]. Maka dari penjelasan diatas, dapat disimpulkan bahwa banyak calon pelanggan yang membutuhkan informasi real-time sehingga dapat mebuat waktu mereka lebih efisien untuk mencari dan memesan produk tersebut.

Agar dapat mengatasi masalah tersebut, maka peneliti membuat penelitian yang berjudul Perancangan Mobile Application Untuk Startup Montirkeliling.com Dengan Metode Design Sprint agar memudahkan calon pelanggan mendapatkan informasi harga dan memudahkan dalam proses pemesanan jasa servis panggilan Montirkeliling.com Adapun tujuan dari penelitian ini berdasarkan latar belakang dan rumusan masalah di atas yaitu untuk mengetahui bagaimana rancangan interface dari mobile application pada Montirkeliling.com.

\section{A. MontirKeliling.com}

MontirKeliling.com merupakan sebuah bisnis yang bergerak di bidang jasa servis. Adapun jasa yang ada pada bisnis ini ialah jasa layanan servis kendaraan (motor), ganti ban, ganti aki, dan layanan derek kendaraan.

\section{B.User Interface}

User interface merupakan media penjembatan antara pengguna dalam berinteraksi dengan sistem sesuai dengan kebutuhan dan keinginan pengguna dengan beberapa pertimbangan yang menjadikan sistem dapat digunakan dengan baik dan tepat [5]

\section{Mobile Apps}

Aplikasi Mobile adalah perangkat lunak yang berjalan pada perangkat mobile seperti smartphone atau tablet PC. Aplikasi mobile juga dikenal sebagai aplikasi yang dapat diunduh dan memiliki fungsi tertentu sehingga menambah fungsionalitas dari perangkat mobile itu sendiri. Untuk mendapatkan mobile application yang diinginkan, pengguna dapat mengunduhnya di situs yang telah disediakan oleh sistem operasi yang digunakan. Bagi pengguna Android dapat menggunakan Google Playstore untuk mengunduh aplikasi yang diinginkan dan pengguna iOS dapat mengunduhnya melalui appstore [6].

\section{Android}

Android merupakan sistem operasi untuk perangkat mobile berbasis linux yang mencangkup sistem operasi, middleware dan aplikasi[8]. Pada awalnya dikembangkan oleh Android Inc, sebuah perusahaan pendatang baru yang membuat perangkat lunak untuk ponsel yang kemudian dibeli oleh Google Inc. Untuk pengembangannya, dibentuklah Open Handset Alliance (OHA), konsorsium dari 34 perusahaan perangkat keras, perangkat lunak, dan telekomunikasi termasuk Google, HTC, Intel, Motorola, Qualcom, T-Mobile, dan Nvidia [9].

\section{E. Design Sprint}

Design Sprint ialah metodologi desain yang dikembangkan oleh Google Inc bertujuan menyelesaikan masalah dengan melibatkan pengguna melalui pembuatan, prototype, perancangan dan pengujian ide dengan cepat. Design Sprint juga dapat diartikan sebagai metode untuk membuat suatu produk yang baru [5].

\section{F. Prototype}

Prototype merupakan sebuah model yang menggambarkan versi awal dari sistem untuk kelanjutan sistem sesungguhnya yang lebih besar[10]. Berdasarkan sifatnya prototipe dibedakan menjadi dua jenis yaitu low fidelity dan high fidelity [11].

\section{KAJIAN TEORI}


e-ISSN: 2685-7006 | p-ISSN: 2252-9063

Kumpulan Artikel Mahasiswa Pendidikan Teknik Informatika

(KARMAPATI)

Volume 10, Nomor 3, Tahun 2021

KคRMAPATI

\section{METODOLOGI PENELITIAN}

\section{A. Metode Penelitian}

Penelitian ini menggunakan mix metod yaitu metode kuantitatif dan kualitatif dengan teknik pengumpulan data menggunakan kuesioner dan wawancara. Dalam penelitian ini metode design sprint digunakan sebagai tahap awal perancangan dari interface aplikasi mobile Montirkeliling.com. Metode design sprint terdiri dari 5 tahapan yaitu seperti pada gambar berikut[12].

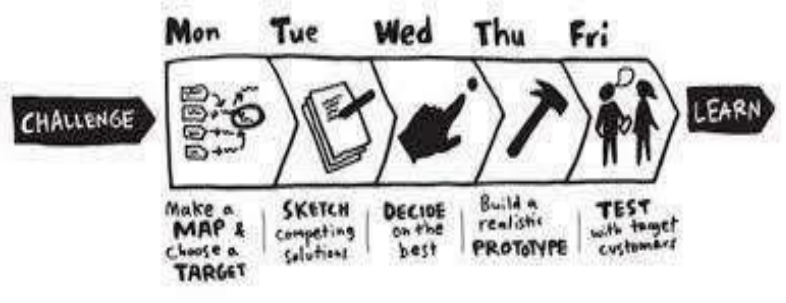

Gambar 1. Lima tahapan metode design sprint

Tahapan metode design sprint terdiri dari 5 tahapan yaitu understand, diverge, decide, prototype, dan validate. Dalam setiap tahapan ini dilakukan secara terurut selama 5 hari kerja yang dimulai dari tahap understand hingga ke tahap validate. Adapun tahapan dalam design sprint seperti berikut.

a. Understand

Pada tahap dihari pertama ini menentukan permasalahan yang ada dengan cara melakukan wawancara dan melakukan benchmark terhadap aplikasi sejenis agar mengetahui kekurangan dan kelebihan aplikasi tersebut.

\section{b. Diverge}

Pada tahap dihari kedua ini mengumpulkan solusi-solusi atau ide-ide yang dimana untuk memecahkan permasalahan yang didapat pada tahap sebelumnya dengan menggunakan cara brainstorming dengan teknik Crazy 8.

\section{c. Decide}

Pada tahap dihari ketiga ini perlu memfokuskan beberapa ide-ide yang ada pada tahap sebelumnya dengan cara melakukan voting yang dimana output-nya akan dibuatkan storyboard dan didiskusikan dengan para ahli.

\section{d. Prototype}

Pada tahap di hari keempat ini membuat prototipe berdasarkan dari hasil yang didapatkan pada tahap sebelumnya yaitu storyboard dengan menggunakan aplikasi pembuatan prototipe seperti Marvel, Figma, Adobe XD dan Invision Studio.

\section{e. Validate}

Pada tahap dihari kelima ini melakukan validasi terhadap prototipe yang dibuat. Tahapan ini juga akan memberikan bagaimana tanggapan terhadap prototipe yang telah dibuat apakah layak dan mudah digunakan.

\section{B. Instrumen Penelitian}

Dalam penelitian, adapun cara yang harus dilakukan peneliti untuk mengumpulkan data data yaitu kuesioner, wawancara dan studi literatur.

\section{Jenis Data}

Adapun jenis data yang akan digunakan dalam penelitian ini adalah kuantitatif dan kualitatif. Dimana data kuantitatif merupakan data yang berupa angka. Data kualitatif merupakan data naratif dan deskriptif. Data kuantitatif diperoleh dari hasil kuesioner sedangkan data kualitatif diperoleh dari hasil wawancara dan observasi. Kuesioner dilakukan kepada calon pelanggan yang mencoba aplikasi. Dari data tersebut, nantinya peneliti dapat menyimpulkan bahwa aplikasi tersebut telah tervalidasi.

\section{Sumber Data}

Sumber data pada penelitian ini adalah dengan menggunakan sumber data primer dan sekunder.

\section{Sumber Data Primer}

Sumber data primer merupakan data yang didapatkan secara langsung yang bersumber melalui data wawancara, kuesioner, dan observasi untuk mengetahui tentang informasi mengenai perancangan dan validasi user interface mobile application Montirkeliling.com.

Penentuan sampel dalam penelitian ini menggunakan teknik slovin dan random sampling untuk mendapatkan sampel. Random sampling ialah suatu cara pengambilan sampel dimana tiap anggota populasi diberi kesempatan yang sama untuk dipilih menjadi sampel[1]. Untuk menentukan jumlah sampel dapat menggunakan rumus slovin seperti pada gambar 3.3 sebagai berikut.

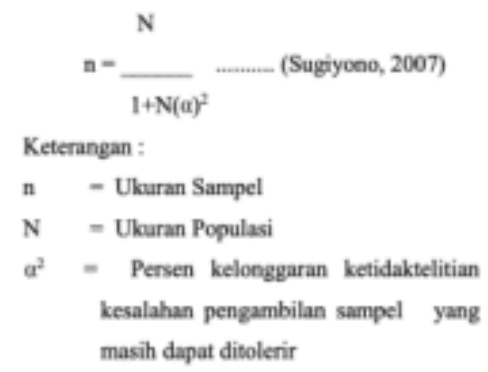

Gambar 1.Rumus Slovin

Sehingga hasil yang didapat dengan menggunakan rumus slovin dari populasi Badung yang yang memeiliki kendaraan dengan rentan umur 17 sampai 40 tahun yang berjumlah 4.261.000 jiwa ialah sebanyak 100 orang. Dari sampel tersebut 
e-ISSN: 2685-7006 | p-ISSN: 2252-9063

Kumpulan Artikel Mahasiswa Pendidikan Teknik Informatika

(KARMAPATI)

Volume 10, Nomor 3, Tahun 2021

\section{KคRmดPดTI}

akan diambil 5-10 orang untuk dijadikan responden dalam fase understand dan validate dalam penelitian ini.

\section{Sumber Data Sekunder}

Sumber data sekunder merupakan data yang didapatkan secara tidak langsung dengan cara mencari informasi dari berbagai sumber terpercaya seperti buku, jurnal, artikel, skripsi dan sumber lainnya mengenai tentang penelitian yang diteliti.

\section{E.Tempat dan Waktu Penelitian}

Penelitian ini dilakukan di Bali yang bertempat di Badung. Adapun penelitian ini dijadwalkan mulai Oktober 2020 sampai April 2021.

\section{F.Alur Penelitian}

Setelah mengidentifikasi masalah dan menentukan teknik pengumpulan data, sumber data apa saja yang digunakan pada penelitian ini, jenis data yang digunakan, menentukan tempat dan waktu penelitian. Berikut merupakan gambar alur penelitian yang dibuat dari mengidentifikasi masalah hingga masuk ke tahapan design sprint, seperti yang digambarkan pada gambar 3.3.

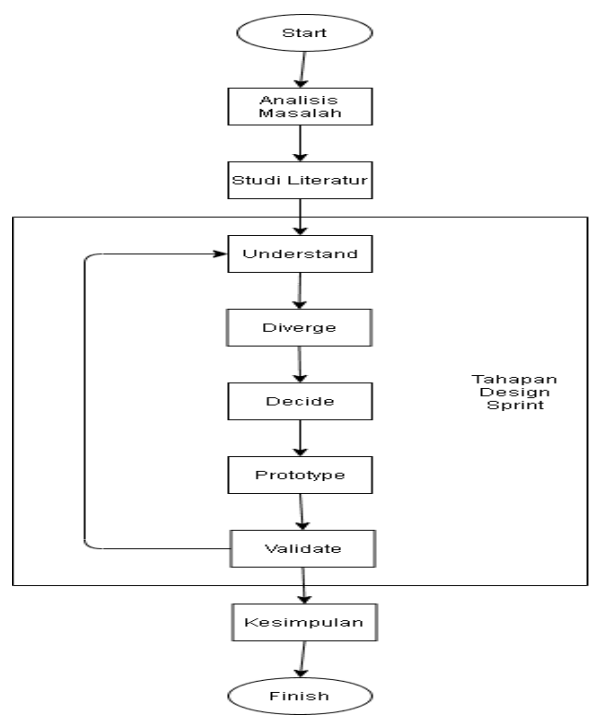

Gambar 2. Alur Penelitian

Alur penelitian ini dimulai dari analisis masalah yang bertujuan untuk memvalidasi masalah dengan melakukan observasi dengan cara menyebarkan kuesioner terhadap 100 responden, yang dimana kuesioner disini telah dilakukan uji normalitas oleh peneliti. Kemudian dilanjutkan dengan studi literatur untuk mencari beberapa referensi terhadap penelitian sebelumnya yang memiliki topik sejenis yang bertujuan sebagai landasan penelitian ini seperti dari berbagai jurnal penelitian mengenai metode design sprint dan system usability scale. Tahap selanjutnya ialah masuk ke dalam tahapan metode design sprint yang terdiri dari 5 fase yaitu understand, diverge, decide, prototype dan validate. Dimana pada tahap validate akan menggunakan metode pengujian sistem SUS (System Usability Scale) untuk mendapatkan hasil yang maksimal ada penelitian ini.

\section{a.Understand}

Populasi pada penelitian ini memilki karakteristik yang memilki kendaraan dengan rentan usia 17 sampai 59 tahun yang berada di kota Badung provinsi Bali sebanyak 4.261.000 orang dan menghasilkan sampel berjumlah 100 orang dengan menggunakan teknik slovin. Dari sampel tersebut akan diambil 10 orang sebagai responden untuk dilakukan wawancara oleh peneliti dengan mengajukan beberapa pertanyaan yang telah disiapkan. Hasil wawancara disini ialah untuk mengetahui kondisi saat ini termasuk permasalahan dari calon pelanggan atau responden saat mengakses aplikasi Montirkeliling.com.

Selain itu peneliti juga melakukan benchmark dengan menguji atau mengakses sendiri terhadap aplikasi dan website sejenis. Hasil dari benchmark tersebut memiliki keunggulan dan kekurangan masing - masing yang dapat dipelajari atau diterapkan pada perancangan aplikasi ini. Setelah mendapatkan hasil dari wawancara maka peneliti akan segera menganalisis dan menjadikan sebagai fokus pembahasan pada tahapan di fase selanjutnya.

\section{b. Diverge}

Pada tahap ini peneliti akan memaparkan semua ide atau brainstroming dari hasil analisis yang telah dilakukan sebelumnya dengan menggunakan teknik Crazy 8 yang memiliki tujuan untuk mengeluarkan semua ide yang dirasa bisa mengatasi masalah yang ada tanpa membatasi ide yang muncul. Adapun langkah untuk memulai teknik ini yaitu:

a) Membagi selembar kertas (letter or A4) dan dilipat menjadi 8 bagian.

b) Menentukan masalah yang akan diselesaikan terlebih dahulu terlebih dahulu.

c) Menuliskan ide atau permasalahan yang dipilih dapat berupa tulisan atau gambar di dalam 8 bagian tersebut. Pada setiap ide utama juga dapat memiliki panel atau penjabaran dari ide utama yang ada. Maksimal panel setiap ide yaitu 3 panel dan ditulis pada sticky note.

\section{c. Decide}

Berdasarkan beberapa ide alternatif solusi yang ada, perlu difokuskan untuk mendapatkan alternatif solusi yang benar benar valid untuk diimplementasikan kepada user. Dalam penelitian ini untuk dapat memfokuskan beberapa alternatif solusi yang ada, maka akan digunakan voting yang akan dilakukan kepada responden yaitu customer dan mekanik. Lalu setelah melakukan voting, peneliti akan membuatkan storyboard dan akan didiskusikan (disini peneliti melakukan wawancara) dengan ahli 
e-ISSN: 2685-7006 | p-ISSN: 2252-9063

Kumpulan Artikel Mahasiswa Pendidikan Teknik Informatika

(KARMAPATI)

Volume 10, Nomor 3, Tahun 2021

KARMAPATI

Storyboard merupakan sketsa gambar yang disusuan berurutan sesuai dengan naskah, dengan storyboard dapat menyampaikan ide cerita atau solusi kepada orang lain dengan lebih mudah, karena dapat menggiring khayalan seseorang mengikuti gambar-gambar yang tersaji, sehingga menghasilkan presepsi yang sama pada ide cerita yang akan disampaikan.

\section{d.Prototype}

Pada tahap ini peneliti akan membuat prototype berdasarkan sketch atau storyboard pada tahap sebelumnya. Berikut merupakan langkah - langkah dalam pembuatan prototype pada penelitian ini:

a) Mengamati sketch atau storyboard yang telah dibuat pada tahapan sebelumnya dan memperkirakan komponen apa saja yang dibutuhkan seperti icon, button dan sejenisnya.

b) Kemudian mencari beberapa komponen tersebut dengan menggunakan beberapa komponen yang didapatkan dari website flaticon untuk menemukan icon dan sejenisnya. Adobe Photoshop (PS) untuk mengedit foto menjadi berkualitas namun memilki size yang kecil.

c) Mengumpulkan dan menata komponen yang dibuat pada satu folder atau file.

d) Export semua komponen dari flaticon, PS, dan sebagainya, kemudian import pada tools untuk membuat prototype. Mengkaji dan mengamati kembali apakah desain yang dibuat sudah sesuai, jika dirasa ada yang perlu diperbaiki atau dibuat lagi dengan tools yang sesuai. Sehingga prototype yang dihasilkan layak untuk diujikan kepada calon pengguna (responden).

\section{e. Validate}

Pada tahap ini peneliti akan menguji atau memverifikasi prototype yang telah dibuat. Adapun responden disini sama seperti yang digunakan pada tahap understand sebelumnya.

Tahap terakhir ialah melakukan dokumentasi dari penelitian yang telah dilakukan yang dimana akan mendapatkan kesimpulan terkait user interface yang sesuai dengan kebutuhan user dan saran diperlukan untuk melanjutkan penelitian ini.

\section{HASIL DAN PEMBAHASAN}

\section{A. Hasil Penelitian}

Dalam penelitian ini, peneliti menggunakan metode design sprint yang memiliki 5 tahapan yang berlangsung selama 5 hari yaitu tahapan understand, diverge, decide, prototype, dan validate. Dalam penelitian ini memilih menggunakan metode tersebut dikarenakan metode ini sesuai dengan tahapan pembuatan prototype yang akan dibuat oleh penelitiBerikut ini adalah penjelasan-penjelasan dari hasil yang dilakukan disetiap tahapan dalam penelitian mengenai perancangan mobile application untuk startup montirkeliling.com dengan menggunakan metode design sprint.

\section{Hasil Tahap Dihari Senin (Understand)}

Berdasarkan hasil wawancara yang telah diperoleh berdasarkan pedoman wawancara yang telah dibuat peneliti yang dapat dilihat pada lampiran 3, dalam tahap pertama dihari Senin (22/03/21) ini, ditemukan beberapa masalah yang dihadapi user. User disini ada dua yaitu dari sisi yang menggunakan jasa (customer) dan dari sisi yang menyediakan jasa (mekanik). Untuk permasalahan yang dihadapi oleh customer yaitu:

1. Kesulitan dalam menemukan servis panggilan diwaktu yang urgent.

2. Memiliki kendala waktu untuk menyervis kendaraan ke bengkel dikarenakan kesibukan yang dimiliki.

3. Masih minimnya informasi mengenai servis panggilan.

Lalu untuk permasalahan yang dihadapi oleh mekanik yaitu:

1. Untuk pemesanan masih sangat manual, karena masih menggunakan media sosial (WhatsApp).

2. Kesulitan dalam melihat lokasi, karena harus menunggu dari customer memberikan lokasinya terlebih dahulu.

3. Kesulitan dalam menemukan order servis panggilan di musim pandemi ini.

Selain melakukan wawancara di tahap ini, peneliti juga melakukan benchmark dengan menguji dan mengakses sendiri terhadap 2 aplikasi sejenis yakni Montir.id dan Bemo ( bengkel motor). Adapun hasil yang didapatkan dari Montir.id yaitu:

1. Aplikasi ini hanya sebatas landing page saja.

2. Menu pada aplikasi tidak dapat diakses.

3. Tidak bisa melakukan login ke aplikasi.

Lalu hasil yang didapatkan dari Bemo yaitu:

1. Sudah ada sedikit perbedaan antara tampilan mekanik dan customer.

2. Aplikasi dapat login dari dua sisi yaitu dari sisi mekanik dan sisi customer.

3. Tampilan pada aplikasi sulit dimengerti.

4. Tombol keluar tidak ada.

5. Pada tampilan mekanik sudah berisikan riwayat dan saldo (total pendapatan).

\section{Hasil Tahap Dihari Selasa (Diverge)}

Pada tahap kedua dihari Selasa (23/03/21) ini dilakukan proses brainstorming dengan menggunakan teknik crazy 8 yang dilakukan oleh peneliti. Adapun hasil yang didapatkan dibagi menjadi dua yaitu dari sisi customer dan sisi mekanik. Adapun hasil yang didapatkan dari sisi customer ialah seperti gambar 1. sebagai berikut.

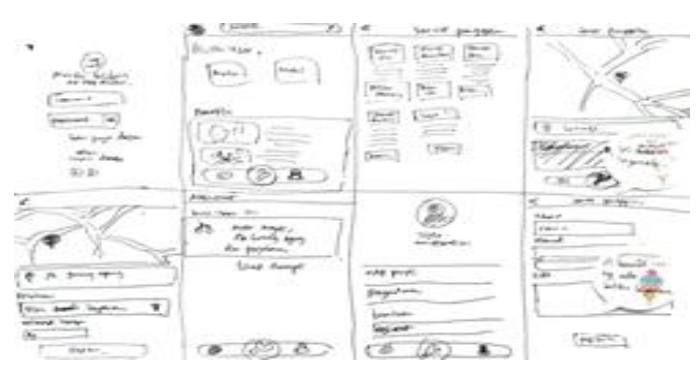




\section{Gambar 1 Hasil crazy 8 customer}

\section{Hasil Tahap Dihari Rabu (Decide)}

Hasil yang didapatkan pada tahap ketiga dihari Rabu (24/03/21) ini yaitu berupa hasil voting yang dilakukan kepada responden (mekanik dan customer) dari ide yang didapatkan dari crazy 8, lalu peneliti menggabungkan ide tersebut dalam storyboard yang telah didiskusikan (peneliti disini melakukan wawancara) dengan ahli. Adapun hasil disini dapat dilihat menjadi 2 sisi, yaitu dari sisi mekanik dapat dilihat pada gambar 2. berikut dan dari sisi customer dapat dilihat gambar 3. berikut.

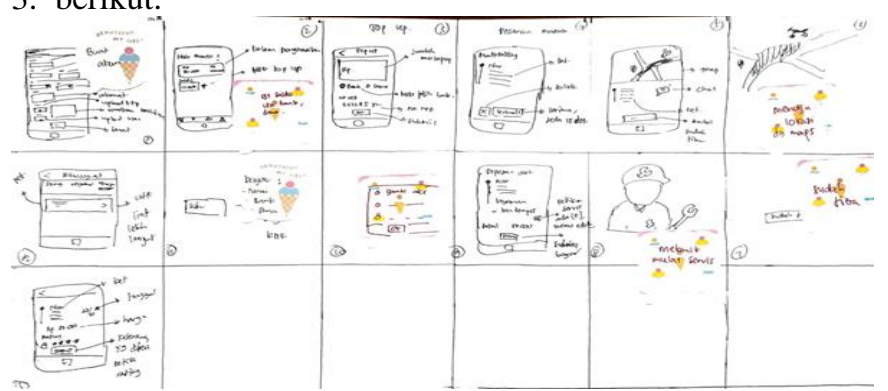

Gambar 2. Storyboard dari sisi mekanik

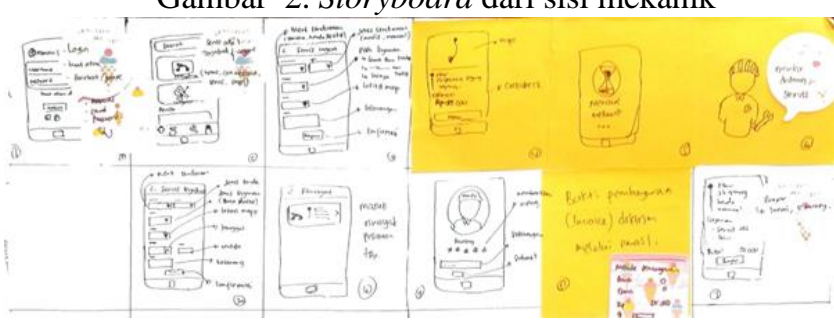

Gambar 3. Storyboard dari sisi customer

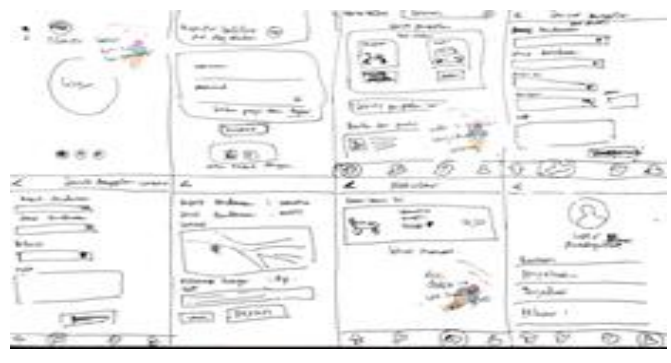

4. Hasil

Tahap

Dihari

Kamis

(Protot ype)

$\mathrm{Pad}$

a tahap

keemp

at dihari Kamis (25/03/21) ini peneliti membuat prototype dari dua sisi yaitu dari sisi customer dan sisi mekanik. Adapun hasil yang didapatkan yaitu sebagai berikut.

\section{Prototype Customer}

\section{A.Tampilan login}

Tampilan ini terdapat kolom username dan password untuk pengguna masuk ke sistem dengan menggunakan username dan password yang sudah didaftarkan atau pengguna bisa masuk menggunakan Facebook dan Gmail. Tampilan pada tampilan masuk ini dapat dilihat pada gambar 3.

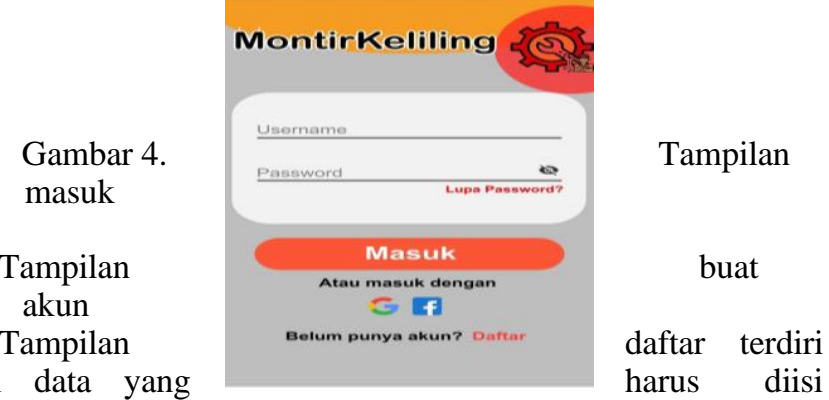
yang terdiri dari nama, telepon, alamat, email dan password. Tampilan daftar dapat dilihat pada gambar 4.

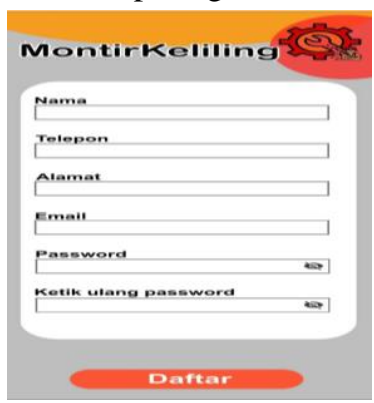

Gambar 5. Daftar Gambar

C.Tampilan beranda

Tampilan beranda terdiri dari 4 menu yaitu beranda, mekanik, aktivitas dan profil. Tampilan beranda dapat dilihat pada gambar 6. 


\section{KARMAPคTI}

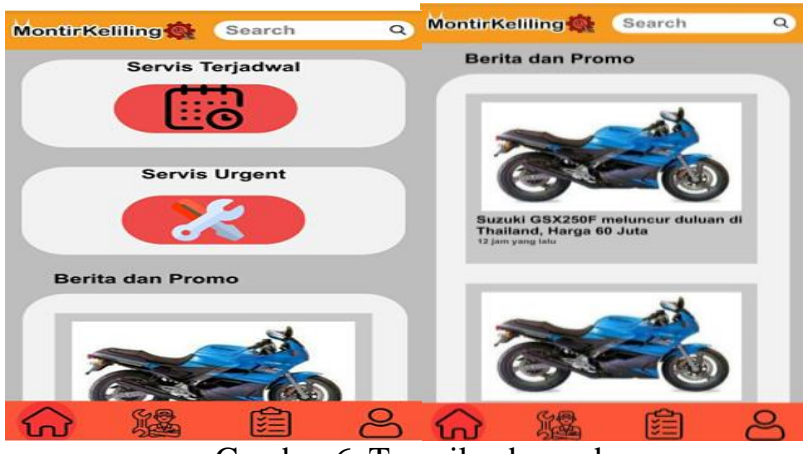

Gambar 6. Tampilan beranda

D.Tampilan servis terjadwal

Pada tampilan ini menampilkan data yang harus diisi oleh pengguna seperti merek, jenis, pilih layanan, lokasi, tanggal, waktu dan catatan. Tampilan servis terjadwal dapat dilihat pada gambar 7.

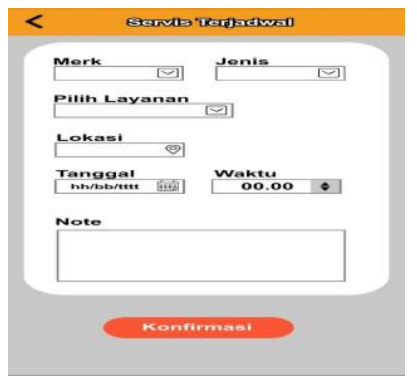

Gambar 7. Tampilan servis terjadwal

Lalu untuk lokasi disini, peneliti membuat agar langsung tersambung dengan maps. Tampilan ini dapat dilihat pada gambar 7 .

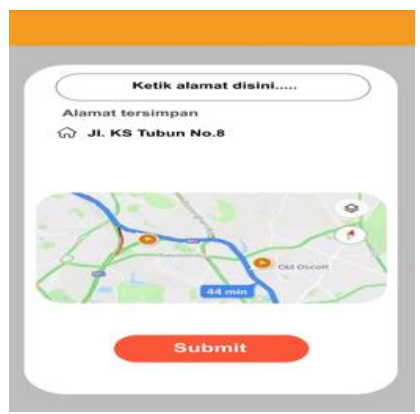

Gambar 7. Tampilan maps alamat

\section{E.Tampilan keterangan servis terjadwal}

Pada tampilan ini menampilkan keterangan lengkap untuk dicek kembali data yang diinput oleh pengguna seperti merek kendaraan, jenis kendaraan, layanan, tanggal, waktu, lokasi yang berbentuk maps, note dan estimasi harga. Dibawah terdapat dua button yaitu button pesan jika sudah benar dan button ubah jika dari data tersebut ada yang ingin diubah. Tampilan ini dapat dilihat pada gambar 8 .

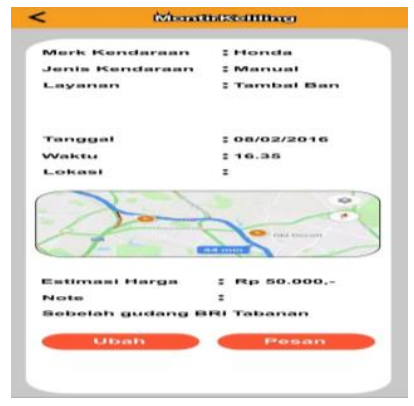

Gambar 8. Tampilan keterangan servis terjadwal

G.Tampilan servis urgent

Tampilan ini berisi form yang harus diisi oleh pelanggan seperti merek, jenis kendaraan, layanan yang dipilih, lokasi dan catatan. Tampilan ini dapat dilihat pada gambar 9 .

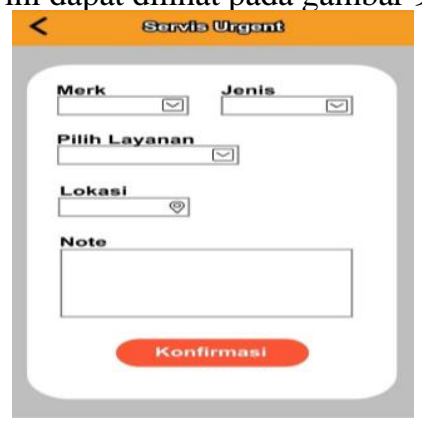

Gambar 9. Tampilan servis urgent

H. Tampilan keterangan servis urgent

Pada tampilan ini berisi keterangan yang telah diisi oleh pelanggan sebelumnya. Tampilan ini dapat dilihat pada gambar 10.

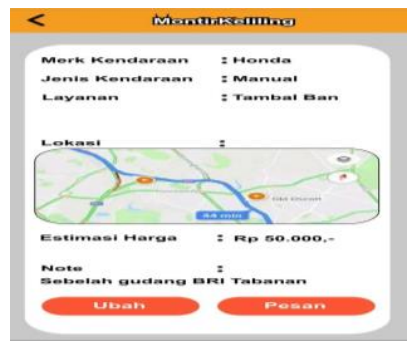

Gambar 10. Tampilan keterangan servis urgent

I.Tampilan mecari mekanik

Pada tampilan ini hanya menampilkan loading ketika mencari atau menemukan mekanik. Tampilan ini bisa dilihat pada gambar 11. 
2685-7006|p-ISSN: 2252-9063

Kumpulan Artikel Mahasiswa Pendidikan Teknik Informatika

(KARMAPATI)

Volume 10, Nomor 3, Tahun 2021

KARMAPคTI

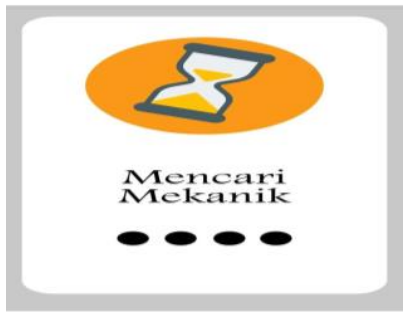

Gambar 11. Tampilan mencari mekanik

J.Tampilan riwayat

Pada tampilan ini menampilkan riwayat dari servis yang pelanggan pernah lakukan lengkap dengan keterangannya. Tampilan ini dapat dilihat pada gambar 12 .

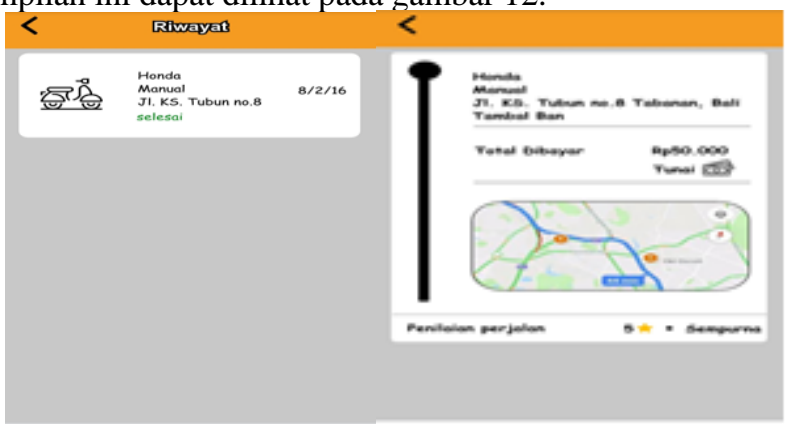

Gambar 12. Tampilan riwayat

K.Tampilan pembayaran dan pemberian rating

Pada tampilan ini menampilkan keterangan lengkap mengenai informasi servis yang telah dilakukan. Tampilan ini dapat dilihat pada gambar 13 .

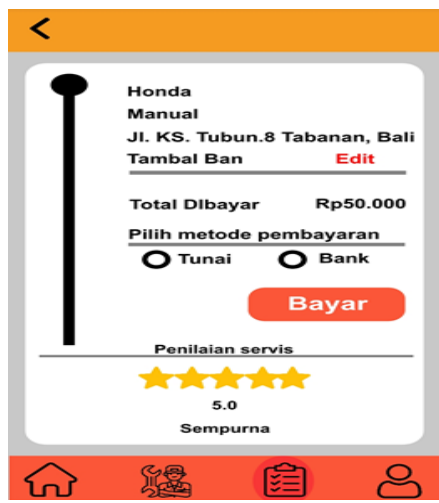

Gambar 13. Tampilan pembayaran dan umpan balik

L.Tampilan informasi mekanik dan layanan

Tampilan ini menampilkan informasi dari rating terbesar ke terkecil dan alamat mekanik tersebut dan berisi tentang keterangan layanan servis yang tersedia di aplikasi. Tampilan ini dapat dilihat pada gambar 14

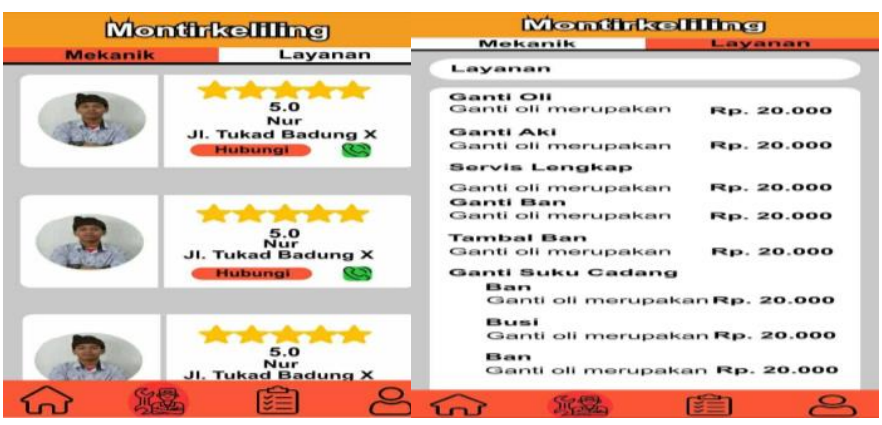

Gambar 14. Tampilan informasi layanan dan mekanik

M.Tampilan chat mekanik

Pada tampilan ini menampilkan fitur chat pelanggan ke mekanik. Tampilan ini dapat dilihat pada gambar 15 .
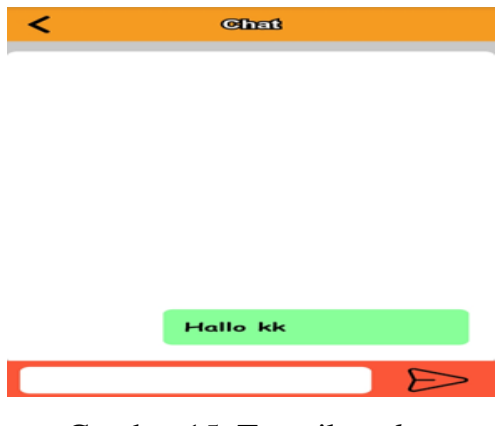

Gambar 15. Tampilan chat

N.Tampilan profile

Pada tampilan ini berisi foto profil, servis terjadwal, bantuan, pengaturan dan untuk keluar akun. Tampilan ini dapat dilihat pada gambar 16 .

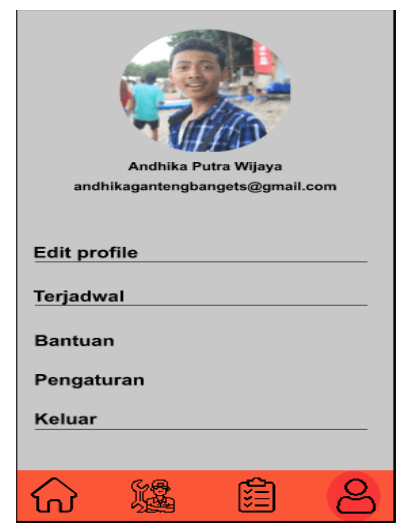

Gambar 16. Tampilan profile

\section{B,Prototype Mekanik}

\section{A.Tampilan login}

Tampilan ini terdapat kolom username dan password untuk pengguna masuk ke sistem dengan menggunakan username dan password yang sudah didaftarkan. Tampilan pada tampilan login ini dapat dilihat pada gambar 17. 
2685-7006|p-ISSN: 2252-9063

Kumpulan Artikel Mahasiswa Pendidikan Teknik Informatika

(KARMAPATI)

Volume 10, Nomor 3, Tahun 2021

KคRMAPคTI

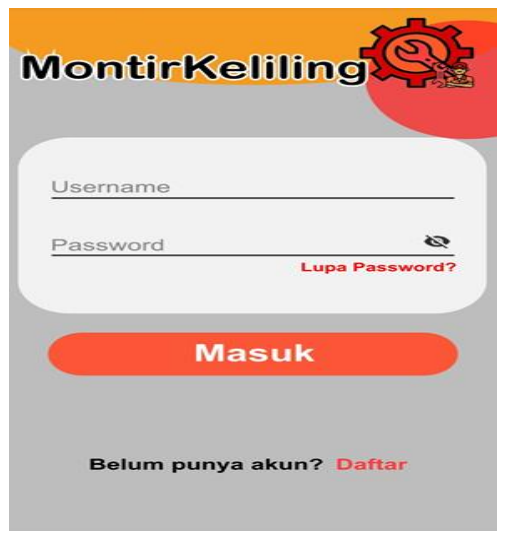

Gambar 17. Tampilan login

B.Tampilan beranda

Pada tampilan ini berisi penghasilan dari mekanik hari ini dan hari kemarin, selanjutnya ada saldo yang dimana digunakan untuk mnerima pesanan dan juga disediakan menu top up saldo. Disini juga terdapat berita dan promo yang berisi mengenai berita-berita seputar motor dan bengkeL. Tampilan pada tampilan beranda ini dapat dilihat pada gambar 18 .

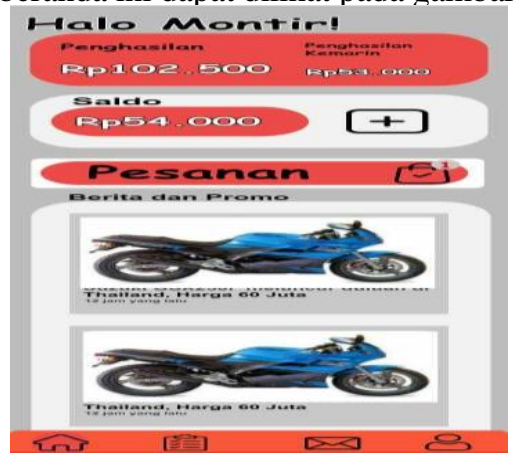

Gambar 18. Tamplan beranda mekanik

C.Tampilan terima pesanan

Pada tampilan ini menampilkan keterangan dari pesanan servis panggilan seperti nama customer, alamat, jenis motor, merek motor, jarak tempuh, kode pesanan dan tariff yang dikenakan. Tampilan pada tampilan terima pesanan ini dapat dilihat pada gambar 19 .

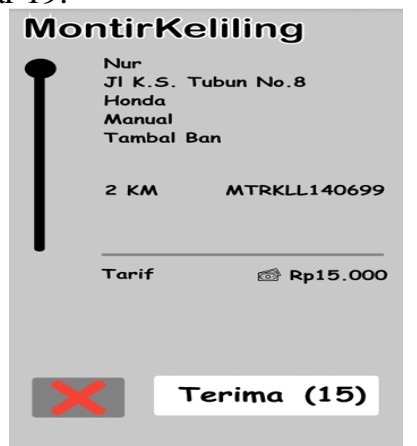

\section{Gambar 19. Tampilan terima pesanan}

\section{D.Tampilan keterangan servis}

Pada tampilan ini berisi alamat pemesan berbentuk berbasis lokasi dengan maps, ada keterangan pesanan, fitur chat dengan customer, dan ada button sudah tiba yang berfungsi jika mekanik sudah tiba bisa mengklik button tersebut. Tampilan pada tampilan keterangan servis dapat dilihat pada gambar 20.

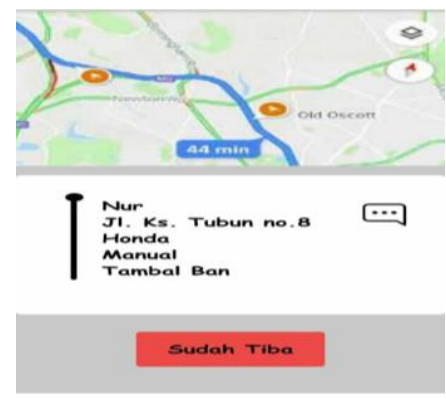

Gambar 20. Tampilan keterangan pesanan

\section{E.Tampilan chat}

Pada tampilan ini menampilkan fitur chat mekanik dengan customer yang bertujuan mempermudah komunikasi antara mekanik dan customer. Tampilan pada tampilan chat ini bisa dilihat pada gambar 21 .

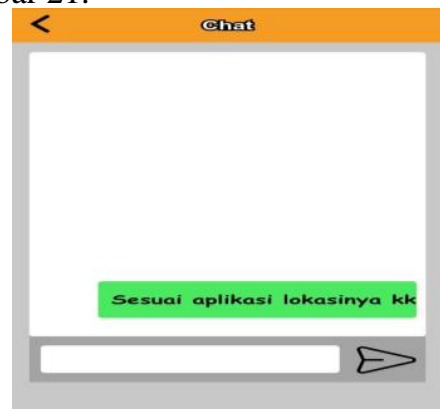

Gambar 21. Tampilan chat

\section{F.Tampilan detail pemesanan}

Pada tampilan ini menampilkan keterangan servis yang telah dilakukan dan pada tampilan ini ada menu untuk menambahkan layanan jika memang kerusakan ada tambahan ketika mekanik menyervis. Lalu dibawah terdapat button selesai servis, button ini akan diklik oleh mekanik jika telah selesai melakukan servis. Tampilan pada tampilan detai pesanan dapat dilihat pada gambar 22 . 


\section{KคRMดPคTI}

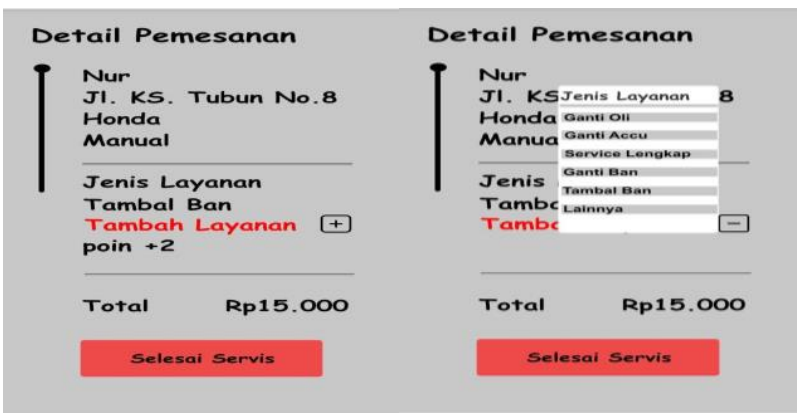

Gambar 22. Tampilan detai pemesanan

\section{G.Tampilan pesanan}

Pada tampilan ini menampilkan pesanan sekarang terjadwal dan riwayat servis yang akan dan sudah dilakukan oleh mekanik. Tampilan pada tampilan pemesan ini dapat dilihat pada gambar 23 .

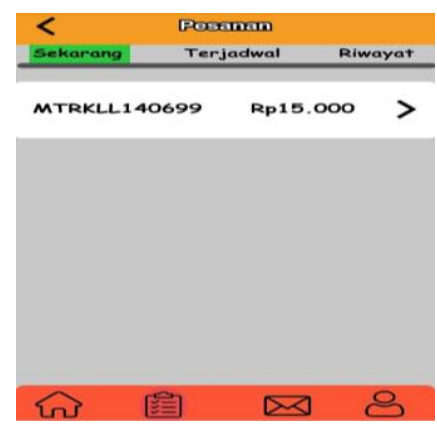

Gambar 23.Tampilan pesanan

H.Tampilan riwayat

Pada tampilan ini menampilkan dari keterangan servis yang telah dilakukan dan ada rating dan umpan balik dari customer mengenai servis yang telah dilakukan oleh mekanik. Tampilan pada tampilan riwayat dapat dilihat dari gambar 24 .

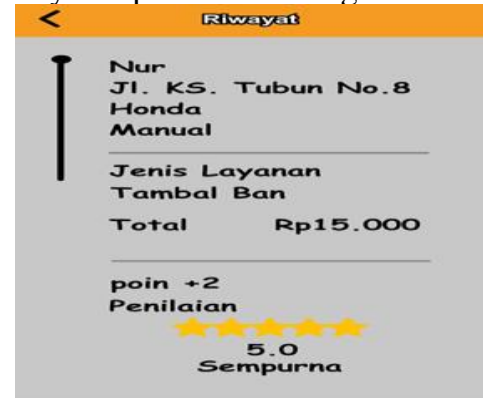

Gambar 24. Tampilan riwayat

\section{I.Tampilan pesan}

Pada tampilan ini menampilkan email yang berisi mengenai berita, info dan promo yang ada kepada pemilik akun. Tampilan pada tampilan pesan ini bisa dilihat pada gambar 25 .

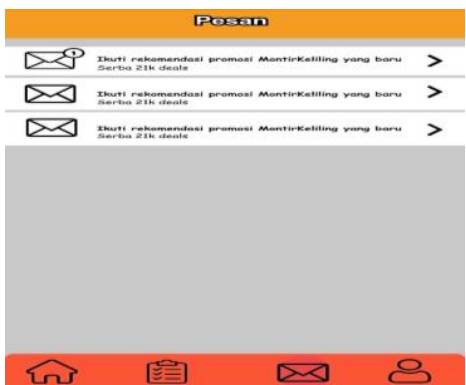

Gambar 25. Tampilan pesan

J.Tampilan profil

Pada tampilan ini menampilkan foto profil dari pemilik akun, berapa rating yang didapatkan, umpan balik yang didapatkan dari customer. Pada tampilan profil terdapat menu edit profil, pengaturan, bantuan dan keluar akun. Tampilan pada tampilan profil dapan dilihat pada gambar 26

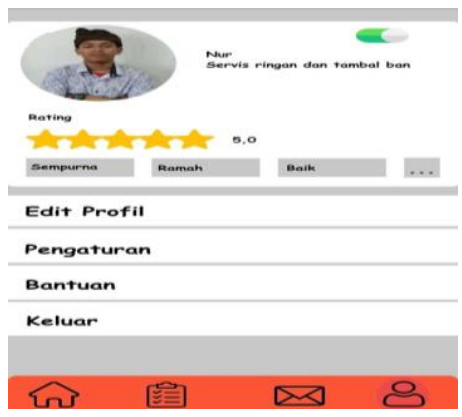

Gambar 26. Tampilan profil

\section{Hasil Tahap Dihari Jumat (Validate)}

Pada tahap kelima dihari Jumat (26/03/21) ini dilakukan proses validasi dengan menguji hasil prototype yang telah dibuat pada tahapan sebelumnya dan mengisi kuesioner yang telah disediakan oleh peneliti. Kemudian pengujian ini terdiri dari 10 responden yang dimana terdiri dari 5 orang customer dan 5 orang mekanik, yang dimana digolongkan lagi berdasarkan umur, yang dimana responden ini merupakan perwakilan bagi pengguna prototype montirkeliling dengan rentan usia 17-40 tahun. Untuk lebih jelasnya bisa bisa dilihat pada tabel 1 .

\begin{tabular}{|c|c|c|c|}
\hline \multicolumn{4}{|c|}{ Customer dan Mekanik } \\
\hline $\begin{array}{c}17-20 \\
\text { tahun }\end{array}$ & $21-24$ tahun & $25-30$ tahun & $31-40$ tahun \\
\hline 2 & 4 & 2 & 2 \\
\hline
\end{tabular}

Tabel 1. Sampel pada tahap validate

Kemudian peneliti akan memberikan prototype aplikasi kepada responden untuk diuji coba oleh responden dan 
e-ISSN: 2685-7006 | p-ISSN: 2252-9063

Kumpulan Artikel Mahasiswa Pendidikan Teknik Informatika

(KARMAPATI)

Volume 10, Nomor 3, Tahun 2021

KดRMAPดTI

selanjutnya memberikan kuesioner kepada responden terkait bagaimana penggunaan aplikasi.

Selanjutnya setelah peneliti melakukan pengujian kepada responden kemudian peneliti merekap hasil dari responden pada kuesioner tertutup, yang selanjutnya akan dihitung menggunakan aturan perhitungan pengujian SUS yang dimana akan mendapatkan hasil layak atau tidaknya prototype yang telah dibuat. Berikut merupakan tabel hasil rekap pada responden, yang terdapat pada tabel 4.1. Untuk lebih jelasnya bisa dilihat pada tabel 2 .

\begin{tabular}{|c|c|c|c|c|c|c|c|c|c|c|c|c|}
\hline \multirow{2}{*}{ No } & Kode & \multirow{2}{*}{$\begin{array}{c}\text { Usia } \\
\text { Responden }\end{array}$} & & \multicolumn{10}{|c|}{ Nilai Responden } & Q.2 & Q.3 & Q. & Q5 & Q6 & Q. & Q. & Q9 & Q10 \\
\hline 1 & R1 & 20 & 2 & 2 & 4 & 1 & 4 & 2 & 4 & 2 & 4 & 2 \\
\hline 2 & R2 & 21 & 4 & 2 & 5 & 1 & 5 & 2 & 5 & 1 & 5 & 1 \\
\hline 3 & R3 & 32 & 5 & 1 & 5 & 1 & 5 & 1 & 4 & 1 & 5 & 2 \\
\hline 4 & R4 & 26 & 4 & 1 & 4 & 1 & 5 & 5 & 4 & 1 & 4 & 1 \\
\hline 5 & R5 & 23 & 4 & 2 & 4 & 2 & 5 & 2 & 4 & 1 & 5 & 2 \\
\hline 6 & R6 & 39 & 4 & 1 & 4 & 1 & 5 & 1 & 4 & 1 & 4 & 2 \\
\hline 7 & R7 & 24 & 4 & 1 & 4 & 1 & 4 & 1 & 4 & 1 & 4 & 2 \\
\hline 8 & R8 & 20 & 5 & 1 & 5 & 2 & 4 & 1 & 4 & 1 & 5 & 2 \\
\hline 9 & R9 & 26 & 4 & 2 & 4 & 2 & 4 & 1 & 3 & 2 & 4 & 2 \\
\hline 10 & R10 & 24 & 3 & 2 & 4 & 2 & 5 & 2 & 3 & 2 & 5 & 2 \\
\hline
\end{tabular}

Tabel 1. Skor responden

Langkah selanjutnya rekap tersebut akan dihitung menggunakan aturan perhitungan SUS, yang dimana jawaban pertanyaan angka ganjil akan dikurangi 1, sedangkan perhitungan jawaban pertanyaan angka genap adalah 5 dikurangi dengan jawaban pertanyaan angka genap, selanjutnya hasil tersebut akan dijumlahkan kemudian dikalikan 2.5 dan mendapatkan hasil dengan rentan angka 1100. Adapun rumus yang digunakan dapat dilihat seperti

$$
\begin{aligned}
\text { Skor SUS }= & ((\mathrm{R} 1-1)+(5-\mathrm{R} 2)+(\mathrm{R} 3-1)+(5-\mathrm{R} 4)+(\mathrm{R} 5-1)+ \\
& (5-\mathrm{R} 6)+(\mathrm{R} 7-1)+(5-\mathrm{R} 8)+(\mathrm{R} 9-1)+(5-\mathrm{R} 10)) \\
& * 2,5)
\end{aligned}
$$

Kemudian didapatkan hasil dengan rumus aturan pada perhitungan SUS, yang dimana peneliti terapkan dengan hasil

\begin{tabular}{|c|c|c|c|c|c|c|c|c|c|c|c|c|c|c|}
\hline \multirow{2}{*}{ No } & \multirow{2}{*}{$\begin{array}{c}\text { Kode } \\
\text { Responden }\end{array}$} & \multirow{2}{*}{ Usia } & \multicolumn{10}{|c|}{ Nilai Responden } & \multirow{2}{*}{ Jumlah } & \multirow{2}{*}{$\begin{array}{c}\text { Nilai } \\
(\text { jumlah } \times 2.5)\end{array}$} \\
\hline & & & Q1 & Q.2 & Q3 & Q4 & Q.5 & Q6. & Q7 & Q8 & Q9 & Q10 & & \\
\hline 1 & R1 & 20 & 1 & 3 & 3 & 4 & 3 & 3 & 3 & 3 & 3 & 3 & 29 & 72.5 \\
\hline 2 & R2 & 21 & 3 & 3 & 4 & 4 & 4 & 3 & 4 & 4 & 4 & 4 & 37 & 92.5 \\
\hline 3 & R3 & 32 & 4 & 4 & 4 & 4 & 4 & 4 & 3 & 4 & 4 & 3 & 38 & 95 \\
\hline 4 & R4 & 26 & 3 & 4 & 3 & 4 & 4 & 0 & 3 & 4 & 3 & 4 & 32 & 80 \\
\hline 5 & R5 & 23 & 3 & 3 & 3 & 3 & 4 & 3 & 3 & 4 & 4 & 3 & 33 & 82.5 \\
\hline 6 & R6 & 39 & 3 & 4 & 3 & 4 & 4 & 4 & 3 & 4 & 3 & 3 & 35 & 87.5 \\
\hline 7 & R7 & 24 & 3 & 4 & 3 & 4 & 3 & 4 & 3 & 4 & 3 & 3 & 34 & 85 \\
\hline 8 & $\mathrm{R} 8$ & 20 & 4 & 4 & 4 & 3 & 3 & 4 & 3 & 4 & 4 & 3 & 36 & 90 \\
\hline 9 & R9 & 26 & 3 & 3 & 3 & 3 & 3 & 4 & 2 & 3 & 3 & 3 & 30 & 75 \\
\hline 10 & R10 & 24 & $2 \mid$ & 3 & 3 & 3 & 4 & 3 & 2 & 3 & 4 & 3 & 30 & 75 \\
\hline & & & & kor & 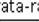 & ata & Tht & & & & & & & 83.5 \\
\hline
\end{tabular}
rekapan kuesioner yang sudah dibuat peneliti. Adapun hasil yang didapatkan dapat dilihat pada tabel 3 . seperti berikut.
Tabel 2. Hasil hitung kuesioner

Berdasarkan pada tabel 3 diatas, hasil pada rumus tersebut dijumlahkan lagi, kemudian mendapatkan hasil senilai 835 selanjutnya hasil tersebut akan dibagi 10, agar mendapatkan nilai rata-rata, setelah itu nilai yang sudah dibagi pada perhitungan tersebut senilai 83,5 , setelah mendapatkan hasil nilai rata-rata tersebut maka langkah selanjutnya adalah menentukan grade prototype yang dibuat apakah dapat diterima oleh pengguna atau tidak. Berdasarkan pada jurnal penelitian Ida Ayu Ratih Ardyantari[2] adapun gambar untuk menentukan nilai grade yang dilakukan oleh John Brooke, yaitu dari tingkat penerimaan pengguna adalah not acceptable, marginal, dan acceptable. Kemudian terdapat grade dari rentan nilai A,B,C,D dan F, yang dimana dengan skor 80,3 atau lebih besar masuk kedalam kategori Grade A, skor rentan 74 sampai 80,3 masuk kedalam Grade B, kemudian untuk Grade C dengan rentan skor 68 sampai 74 sedangkan untuk Grade D dengan rentan 51 sampai 68, dan Grade F dengan skor 51 kebawah. Pada adjecktif rating terdiri dari worst imaginable, poor, ok, good, excellent dan best imaginable. Nilai ini digunakan untuk melihat sejauh mana pandangan pengguna pada prototype prototype yang telah peneliti buat di tahap sebelumnya. Gambar penentuan hasil penilaian dapat dilihat pada gambar 27 .

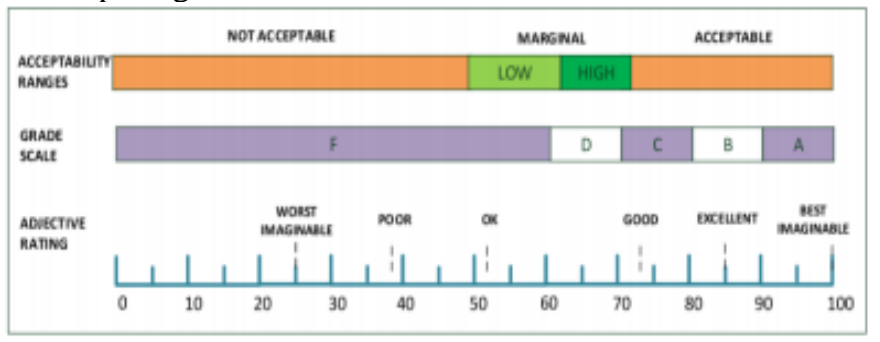

Gambar 27. Hasil penilaian

Berdasarkan pada nilai-nilai pada grade diatas dapat disimpulkan bahwa prototype yang telah dibuat dapat diterima oleh penggunanya, hal ini dapat dibuktikan pada Grade adjective rating excellent dengan hasil rata rata 83,5 dan masuk Grade B dapat menjadi aplikasi booking yang 
e-ISSN: 2685-7006 | p-ISSN: 2252-9063

Kumpulan Artikel Mahasiswa Pendidikan Teknik Informatika

(KARMAPATI)

Volume 10, Nomor 3, Tahun 2021

KARMAPATI

memudahkan customer mencari mekanik dan memudahkan mekanik menggunakannya.

\section{Pembahasan Validasi}

Pengujian prototype dilakukan kepada penduduk kabupaten Badung dengan mengambil 10 responden. Dalam pengujian ini, metode yang digunakan ialah metode System Usability Scale (SUS). Metode System Usability Scale (SUS) ini berupa pengajuan kuesioner yang berisi 10 pertanyaan dengan 5 parameter jawaban. Masing-masing pertanyaan memiliki parameter jawaban dengan skor $1 \mathrm{~s} / \mathrm{d} 5$, dimana skor 1 adalah jawaban sangat tidak setuju, hingga 5 untuk jawaban sangat setuju. Hasil tabel data pengujian dengan menggunakan metode SUS tahap pertama dapat dilihat pada tabel 1.sebagai berikut:

\begin{tabular}{|c|c|c|c|c|c|c|c|c|c|c|c|c|}
\hline \multirow{2}{*}{ No } & Kode & \multirow{8}{*}{ Usia } & \multicolumn{10}{|c|}{ Nilai Responden } \\
\cline { 5 - 13 } & Responden & & $\mathrm{Q} 1$ & $\mathrm{Q} 2$ & $\mathrm{Q} 3$ & $\mathrm{Q} 4$ & $\mathrm{Q} 5$ & $\mathrm{Q} 6$ & $\mathrm{Q} 7$ & $\mathrm{Q} 8$ & $\mathrm{Q} 9$ & $\mathrm{Q} 10$ \\
\hline 1 & $\mathrm{R} 1$ & 20 & 2 & 2 & 4 & 1 & 4 & 2 & 4 & 2 & 4 & 2 \\
\hline 2 & $\mathrm{R} 2$ & 21 & 4 & 2 & 5 & 1 & 5 & 2 & 5 & 1 & 5 & 1 \\
\hline 3 & $\mathrm{R} 3$ & 32 & 5 & 1 & 5 & 1 & 5 & 1 & 4 & 1 & 5 & 2 \\
\hline 4 & $\mathrm{R} 4$ & 26 & 4 & 1 & 4 & 1 & 5 & 5 & 4 & 1 & 4 & 1 \\
\hline 5 & R5 & 23 & 4 & 2 & 4 & 2 & 5 & 2 & 4 & 1 & 5 & 2 \\
\hline 6 & R6 & 39 & 4 & 1 & 4 & 1 & 5 & 1 & 4 & 1 & 4 & 2 \\
\hline 7 & R7 & 24 & 4 & 1 & 4 & 1 & 4 & 1 & 4 & 1 & 4 & 2 \\
\hline 8 & R8 & 20 & 5 & 1 & 5 & 2 & 4 & 1 & 4 & 1 & 5 & 2 \\
\hline 9 & R9 & 26 & 4 & 2 & 4 & 2 & 4 & 1 & 3 & 2 & 4 & 2 \\
\hline 10 & R10 & 24 & 3 & 2 & 4 & 2 & 5 & 2 & 3 & 2 & 5 & 2 \\
\hline & Rata-rata & & 3.9 & 1.5 & 4.3 & 1.4 & 4.6 & 1.8 & 3.9 & 1.3 & 4.5 & 1.8 \\
\hline
\end{tabular}

Tabel 4. Tabel SUS (1)

Dalam metode SUS ini pertanyaan yang ada selalu bersaling, dimana pertanyaan ganjil bernada positif dan genap bernada negatif. Dari pengujian yang dilakukan peneliti lakukan terlihat bahwa responden setuju ingin lebih sering menggunakan prototype yang telah dibuat, hal ini dapat dibuktikan dengan 6 dari 10 responden mengatakan setuju, 3 responden mengatakan sangat setuju dan 1 responden mengatakan tidak setuju dikarenakan responden selalu ketika mogok kendaraanya tidak kesulitan dalam menenukan mekanik karena mogok di dekat mekanik. Responden menilai tidak setuju jika prototype ini tidak perlu dibuat serumit ini, hal ini dibuktikan dengan 5 dari 10 responden mengatakan tidak setuju dan 5 responden mengatakan 5 orang sangat tidak setuju.

Responden menilai setuju prototype ini mudah untuk digunakan, hal ini dapat dibuktikan dengan 7 dari 10 responden mengatakan setuju dan 3 responden mengatakan sangat setuju.

Responden menilai sangat tidak setuju bahwa akan membutuhkan bantuan dari orang teknis untuk dapat menggunakan prototype ini, hal ini dapat dibuktikan dengan 6 dari 10 responden menyatakan sangat tidak setuju dan 4 responden mengatakan tidak setuju.
Responden menilai setuju bahwa berbagai fungsi prototype ini terintegrasi dengan baik, hal ini dapat dibuktikan dengan 4 dari 10 responden menyatakan setuju dan 6 responden mengatakan sangat setuju. Responden menilai sangat tidak setuju bahwa ada banyak ketidaksesuaian didalam prototype ini, hal ini dapat dibuktikan dengan 5 dari 10 responden mengatakan sangat setuju, 4 responden mengatakan setuju dan 1 responden mengatakan sangat setuju dikarenakan respoden salah mengira parameter 5 adalah sangat tidak setuju.

Responden menilai setuju bahwa kebanyakan orang akan mudah untuk mempelajari prototype ini, hal ini dibuktikan dengan 7 dari 10 responden mengatakan setuju, 1 responden mengatakan sangat setuju dan 2 responden mengatakan netral. Responden menilai sangat tidak setuju bahwa prototype ini sangat rumit untuk digunakan, hal ini dapat dibuktikan dengan 7 dari 10 responden mengatakan sangat tidak setuju dan 3 responden mengatakan tidak setuju.

Responden menilai setuju bahwa merasa percaya diri untuk menggunakan prototype ini, hal in dapat dibuktikan dengan 5 dari responden mengatakan setuju dan sangat setuju. Responden menilai tidak setuju bahwa perlu belajar banyak hal sebelum bisa menggunakan prototype ini, hal ini dapat dibuktikan dengan 8 dari 10 responden mengatakan tidak setuju dan 2 responden mengatakan sangat tidak setuju.

Dari data tabel SUS diatas, dilihat dari nilai total rata-rata pertanyaan bahwa dari segi penggunaan prototype ini sudah mampu digunakan dengan baik dan bukan tipikal aplikasi rumit.

\section{V.PENUTUP}

Berdasarkan dari pembahasan yang telah peneliti uraikan dibab-bab sebelumnya tentang perancangan mobile application Montirkeliling.com dengan menggunakan metode design sprint dapat ditarik kesimpulan bahwa pada metode ini cocok untuk tahap awal dalam perancangan sebuah sistem dikarenakan proses pada metode ini relatif cepat dan efektif yaitu dalam 5 hari kerja yang dimana hasil yang didapatkan sudah menjawab dari permasalahan yang ada. Metode ini terdiri dari 5 tahapan yang dimana masing-masing tahapan tersebut dilakukan dalam 1 hari.Adapun hasil skor rata-rata SUS yang didapatkan yaitu 83.5 yang mendapatkan Grade Scale B dan Grade Adjective Rating Excellent. Berdasarkan grade diatas maka dapat disimpulkan prototype yang dibuat dapat diterima oleh pengguna, memudahkan customer dalam menemukan mekanik dan memudahkan mekanik dalam menggunakannya. Dalam penelitian ini user interface yang dihasilkan ada dua tampilan yaitu tampilan dari sisi mekanik dan customer. Dari sisi customer terdiri dari tampilan login, signup, beranda informasi layanan dan mekanik, riwayat, profil, chat dan memesan jasa layanan. Dari sisi mekanik terdiri dari tampilan login, signup, beranda, chat, pesanan, riwayat, pesan dan profil.

Adapun saran yang ingin peneliti ingin sampaikan, jika ada yang ingin melakukan penelitian dengan tema atau topik yang sama yaitu perancangan dengan metode design sprint, agar 
e-ISSN: 2685-7006 | p-ISSN: 2252-9063

Kumpulan Artikel Mahasiswa Pendidikan Teknik Informatika

(KARMAPATI)

Volume 10, Nomor 3, Tahun 2021

KคRMดPดTI

dapat mempertimbangkan saran dari peneliti, diantaranya 1) Dalam perancangannya harap memperhatikan kaidah-kaidah dalam pembuatan User Interface dari setiap OS baik Android maupun IOS. Karena setiap OS memiliki karakteristik yang berbeda-beda, 2) Dalam tahap decide diperluhkan ahli untuk melakukan diskusi, dan agar mudah dalam menentukan ahli tersebut. Peneliti menyarakan agar peneliti selanjutnya dapat membuat beberapa kiteria ahli yang diperluhkan entah dari segi UI/UX nya atau dari segi proses bisnisnya dari referensi jurnal atau artikel yang ada, 3) Dalam metode design sprint ini diharapkan pada penelitian selanjutnya untuk melakukan dokumentasi pada setiap tahapan yang ada yang dimana bertujuan untuk menguatkan argument peneliti apakah benar metode ini dilakukan dalam 5 hari.

\section{REFERENCES}

[1] B. P. S. Bali, Statistik Daerah Provinsi Bali 2020, no. 1. Denpasar: Badan Pusat Statistik Provinsi Bali, 2020.

[2] I. R. A. Ayu, N. L. P. S. P. Astawa, I. P. Satwika, and A. A. A. P. Ardyanti, "Griyamua Interactive Android Dengan Firebase Dan React Native," Jutisi J. Ilm. Tek. Inform. dan Sist. Inf., vol. 8, no. 3, pp. 75-84, 2019.

[3] lucia maria aversa Villela, "Perancangan dan Implementasi Sistem Informasi e-Marketplace untuk Katering," J. Chem. Inf. Model., vol. 53, no. 9, pp. 1689-1699, 2013.

[4] P. S. Arta, "Rancang Bangun Sistem Informasi Marketplace Penyewaan Lapangan Futsal Berbasis Web," J. Teknol. dan Manaj. Inform., vol. 4, no. 2, 2018, doi: 10.26905/jtmi.v4i2.2229.

[5] R. Ramadan, H. M. Az-Zahra, and R. I. Rokhmawati, "Perancangan User Interface Aplikasi EzyPay menggunakan Metode Design Sprint (Studi Kasus PT. Arta Elektronik Indonesia)," J. Pengemb. Teknol. Inf. dan Ilmu Komput. e-ISSN, vol. 2548, no. 9, p. 964X, 2019.

[6] M. Irsan, "Rancang Bangun Aplikasi Mobile Notifikasi Berbasis Android Untuk Mendukung Kinerja Di Instansi Pemerintahan," J. Penelit. Tek. Inform., vol. 1, no. 1, pp. 115-120, 2015.

[7] M. Ikhsan, "Survey Loyalitas : Pengguna Android Lebih Loyal dari iOS," CNN Indonesia, 2020. https://www.cnnindonesia.com/teknologi/20200727163507 -185-529443/survei-loyalitas-pengguna-android-lebihloyal-dari-ios (accessed Nov. 12, 2020).

[8] Murtiwiyati and G. Lauren, "Rancang Bangun Aplikasi Pembelajaran Budaya Indonesia Untuk Anak Sekolah Dasar Berbasis Android," vol. 12, pp. 1-10, 2013.

[9] M. Ichwan and F. Hakiky, "Pengukuran Kinerja Goodreads Application Programming Interface (API) Pada Aplikasi Mobile Android," vol. 2, no. 2, pp. 13-21, 2011.

[10]M. Muraqabatullah, "Komparasi Perangkat Lunak HighFidelity Prototyping: Marvel Dan Uxpin Pada Pengembangan Aplikasi Web Learning Management System ( Lms )," Univ. Islam Indones., pp. 1-8, 2018.

[11]K. Wong, "Rancang Bangun Aplikasi 'Trip Alone?' Berbasis Android," J. Tek. Inform., vol. 9, no. 1, 2016, doi: 10.35793/jti.9.1.2016.14809.

12]K. Wong, "Rancang Bangun Aplikasi 'Trip Alone?' Berbasis Android," J. Tek. Inform., vol. 9, no. 1, 2016, doi: 10.35793/jti.9.1.2016.1480 